\title{
13 Stability and Change in Scandinavian Welfare: The Nonprofit Sector as a Buffer against For-Profit Expansion
}

In 1984, as a reaction to conservative calls for the introduction of for-profit providers in day care for children, the ruling Swedish social democrats passed a special law prohibiting the flow of any public money to private day care for children. This was in spite of long queues and a general inability to offer sufficient public supply (Rothstein, 1993). This hostility to for-profit providers was also reflected in the statement by prime minister Olof Palme that the public school was 'a spearhead into the future classless society', something which may explain why the share of children in private schools was as low as 0,2 per cent in the mid-1980s (Blomqvist, 2004, p. 157).

Today, approximately 30 years later, for-profits have gained a market share of around 20 percent of welfare services in Sweden, and their share of welfare is growing at accelerating speed (Sivesind, 2017). In Stockholm, users of public home care services for the elderly must choose from among more than 100 providers in each district. The competition has led to almost 40 percent of the providers having names that starts with an A, and some even choosing names beginning with AAA, to increase their likelihood of being chosen (Szebehely, 2014).

This example documents that changes have taken place in some of the core institutional arrangements in the Nordic welfare system. Interestingly, this change is not paralleled in Denmark and Norway, prompting questions about what conditions have made Sweden take, in some ways, a radically different path than their Scandinavian peers. This is in spite of the welfare goals in all three countries increasingly focusing on democratic values, such as personal autonomy, personal choice and moving power from public bureaucrats to the citizens (Rostgaard, 2015, p. 4). The means for reaching these goals is what is different.

Looking at this period of time, from the 1990s to today, in this chapter I use schools and elderly care as examples to show the depth of the changes, explain the institutional prerequisites for change and reflect upon the future of the Scandinavian welfare model. The changes are important because the nature of the welfare services constitutes a main outcome of the Scandinavian electoral democracy. It is thus important to understand the room elected representatives have to make choices about the welfare mix - the division of public, nonprofit and for-profit providers - and the context where they make such decisions. Furthermore, inasmuch as providers from the different sectors are different, it can spur a plurality of service content that enables citizens to get services in accordance with their individual preferences at the same time as it may challenge important values such as equity. 
The central argument of the chapter is that even if the three countries have all embraced increased use of for-profit providers since the 1990s, developments have been different due to the historical role of the nonprofit sector. In Denmark and Norway a tradition with active interaction between the government and nonprofit actors means that the welfare system has ended up with two layers of government relations to non-public providers: the traditional regime for government-nonprofit interaction and the quasi markets where for-profits compete. In Sweden, the nonprofit sector was not at a level where its interaction with the government represented an independent government structure. The relationship between the state and non-public providers thus has only one layer: the quasi market where for-profit providers dominate.

The chapter starts with a brief update on the relevant theories for institutional change. This is followed by a description of the main characteristics of Scandinavian welfare services, the pressures for change they experience and the changes that actually take place. Finally, I make a comparative discussion of why we see different kinds and degrees of institutional change in Sweden compared to Denmark and Norway.

\subsection{Institutional Change - Critical Juncture and Incremental Steps}

Institutions are in this chapter understood as formal or informal regulations that constrain the behaviour of individuals and groups. Policy areas, such as schools and elderly care, involve both legally binding and informal constraints on behaviour, are powerful in shaping resources and incentives for political actors and are normally durable arrangements (Pierson, 2004, pp. 34-35).

A central notion in historical institutionalism is that of path dependency, which depicts institutions profoundly stable under normal conditions. The approach underscores the importance of sequences and that the timing of events is crucial. It gives useful guidance to focus the analysis on the historical elements of a process as choices early in the process limit the room for choices at later stages, and earlier decisions made thus have greater implications at a later stage (Pierson, 2000). The question of policy initiation is a central issue for the path-dependency approach - the point in history where the path was chosen and where later decisions were locked in. Decisions made at these critical junctures will guide future developments in the field and thus explain later trajectories.

To understand the critical junctures where decisions lock in developments on a path, students of institutional change have focused on the importance of situations of large-scale public dissatisfaction stemming from an unusual degree of social unrest. Wars, economic crises or a change in the balance of power are examples of what may produce a mandate for an alternative policy. When these situations of shock open a window of opportunity for new rules and a new course of action, these will endure until the next shock sets the development on yet another path (Hogan, 2006, p. 664). 
A challenge to the idea of path dependency and the need for critical junctures to produce important changes is that institutions such as a welfare model, or a policy field, are the subject of constantly ongoing actions. These actions will not individually lead an institution out of its path, but many of these actions can together have significant aggregate effects, even if no shock has created a window of opportunity for radical change. Kathleen Thelen and colleagues have described mechanisms (layering, displacement, drift, conversion) that reflect the agency of individuals as they gradually create change through incremental steps (Mahoney \& Thelen, 2010; Streck \& Thelen, 2005). Most relevant for this analysis are the concepts of layering and conversion. Layering involves the placing of new constituents in an established institution's framework. This can see new initiatives introduced to address contemporary demands but then adding to, rather than replacing, preexisting institutional forms. Consequently, older institutions will often have a highly 'layered' quality. 'Conversion occurs when the formal rules are the same, but are interpreted and enacted in new ways' (Mahoney \& Thelen, 2010, p. 17). The new functions of the rules result from actors who strategically exploit the ambiguities of the institution to reshape it in accordance with their interests. Since conversions often occur when there are weak veto possibilities and high levels of discretion in interpretation or enforcement, conversion is the form of aggregate incremental development that often yields the most comprehensive results (Mahoney \& Thelen, 2010, p. 19).

As much as these theories of institutional change have been developed and presented in opposition to each other, there are no serious inconsistencies between them. Indeed, they can be regarded as supplementary explanations for institutional change (Engelstad \& Hagelund, 2015, p. 10).

\subsection{Central Features of the Nordic Welfare System}

This chapter is focused on the service component of the Nordic welfare system. This means that issues such as transfers and entitlements are put to the side, and other questions arise: Who finances, regulates and provides the services? And who receives them?

Indeed, it has been argued that it is particularly in the service sector that Scandinavian welfare is most distinct and that this is where one finds the key to Scandinavian exceptionalism (Sipilä, 1997). The special traits that set Scandinavia apart are that the services are financed by taxes, the state has a regulatory monopoly and the public sector dominates in providing the services.

The public provision of services is by Lehto, Moss and Rostgaard (1999) claimed to be the most important characteristic of the Nordic system. Compared to other Western countries, the dominance of the public sector in welfare provision is a shared phenomenon. Yet, there are important intra-Scandinavian differences. Historically, 
the Swedish public sector has been more dominant than in Denmark and Norway. Since the for-profit sector has played a limited role in all three countries this variation is mainly explained through the role of the nonprofit sector. Denmark has a long tradition of nonprofit supplement to public provision, currently at about 14 percent of the welfare, Sweden has probably the smallest nonprofit sector in the Western world with only 3 per cent, while Norway is in between with 8 percent nonprofit welfare (Sivesind, 2017). These numbers have been stable over a long time.

When it comes to who receives the services, the short answer is: everyone. That is to say, for core services such as health care, education and social care, there is no economic needs testing. However, there is an important downside of granting everyone the same access to the same services: people are different from each other. Twenty years ago Bo Rothstein (1998) described the term 'high quality standard solution'. The meaning was that the Nordic welfare systems were aiming so high that all walks of life should be happy with the service. At the same time the standard solution implied that there was little room for deviating preferences. Rothstein foresaw this as a major challenge for Nordic welfare in its future development. In the decades that have passed, calls for individual empowerment through user choice have increased as a natural next step for expanding the democratic control of citizens (Blomqvist \& Rothstein, 2008; Kumlin, 2004, p. 56; Solevid, 2009).

\subsection{Welfare Mix and Democracy}

While it is important to identify the central tenets of the organization of the welfare model, it is also important to reveal why this organization was chosen - what was intended to be achieved. This is what gave the model democratic legitimacy. The goal formulated most forcefully in the postwar period was to achieve equality in opportunities (and equity in outcomes). Market forces were, in the welfare area, seen as a threat to these goals. For government to take control of all aspects of the services was therefore a) an efficient manner to rein in market forces, b) a tool for the democratic self-rule governance of important aspects of people's lives and c) a modern, collective way to build the desired society (Sejersted, 2011, pp. 120-121). A result of these ambitions is that Scandinavian public sector institutions traditionally have had a reputation for enabling citizens to take control of their own lives in care situations where they depend on the welfare state (Andersen \& Hoff, 2001; Andersen \& Rossteutscher, 2007; Petersson, Westholm, \& Blomberg, 1989).

Controlling citizens' meeting points with public services through having public provision of core services was thus a central ambition in the founding years of the Scandinavian welfare model. The importance of this citizen-public institution encounter seems just as relevant today, however, since evidence suggests that much of the legitimacy of Scandinavian democracy is determined on the output side where citizens experience the results of political decisions. Welfare services are core 
areas where citizens experience such results (Gustavsen, Røiseland, \& Pierre, 2014; Rothstein, 2009).

Developments in the welfare mix - the division of public, nonprofit and for-profit providers - are important when they influence the outcome of political processes. This influence can be based on inherent differences between the different providers. Research on the importance of the welfare mix suggests that providers from different sectors are inherently different (Salamon, 1987; Steinberg, 2006). These differences can take the form of catering to different groups in society (Weisbrod, 1988), how they include users in decision-making at the institutions (Trætteberg, 2016a) and how they relate to volunteers (Chaves, 1998; Young, 2013).

At the same time, there is a vast body of literature on how market-inspired mechanisms such as user choice schemes and public tenders affect services. Both from a political (Blomqvist \& Rothstein, 2008) and economic (Le Grand, 2007) perspective it is argued that user choice empowers users through moving power from public bureaucrats to the concerned citizen. In addition, if the options users can choose between are substantively different, this also represents a democratic expansion of the autonomy of users since more citizens get services tailored to their preferences (Trætteberg, 2016b).

The key point is that for Scandinavian democracy the nature of the welfare services matters. Such services are an outcome of democratic processes which can be assessed by examining how citizens experience the services. As I argue above, the ability for citizens to obtain high-quality service in accordance with their preferences and which are amenable to user influence are central features to include in assessments of Scandinavian welfare.

\subsection{Service Areas}

Schools and elderly care are core features of the modern Scandinavian welfare model; together with health care, they constitute the main pillars of the welfare states. In all three countries they are municipal services. Take away care for the elderly and education and there is no Scandinavian welfare model.

Schools have a long standing as a tool for developing society. Their history goes back centuries, and the formation of a national, integrated school system goes back to the mid-1800s (Thuen \& Tveit, 2013). The control of education has always been an important indicator of power relations in society, with the state trying to wrest control from churches and other non-public entities.

Public responsibility for elderly care is a more recent phenomenon and can be traced back to the first half of the last century. Before this elderly care was the responsibility of the families with some efforts from nonprofit organizations (Daatland, 1997). In broad terms municipal elderly care consists of care in nursing homes and care where the elderly receive care in their own homes. 


\subsection{The Nature of the Change}

Martin Seeleib-Kaiser (2008) identifies three factors that can explain calls for greater emphasis on private arrangements in welfare systems. First, globalization limits the economic room for states to manoeuvre. Second, societies are rapidly aging, something that puts pressure on the public purse. Third, an ongoing process of individualization involves citizens' demand for more choice and individual decision-making, also as users of public services.

These challenges are almost universally present, and they must be addressed. Interestingly, new public management (NPM) solutions with the use of marketemulating steering tools and private actors have gained (near) universal foothold as one answer to these challenges (Pollitt \& Bouckaert, 2011, pp. 6-7). Even if these tools are introduced to varying degrees and in different forms, some versions of them are present over practically the entire Western world.

To identify and understand institutional change one needs to know where to look. As we saw, what is distinctive in the Nordic welfare system is the financing and regulation of services as well as the public dominance of provision. These are all aspects challenged by the external forces suggesting that profound changes in the welfare system may take place. We must thus look at changes in who finances, regulates and provides the service.

In the following, I analyze the developments in the three Scandinavian countries when it comes to these issues. I first look at the school sector and then elderly care.

\subsection{Schools}

In building the Nordic welfare systems in the postwar period, schools were heavily influenced by a reform-pedagogic theory where the ideal was to be pupil-centred, with space for the pupils to be spontaneous and creative (Telhaug, Mediås, \& Aasen, 2006). In the 1990s, this changed in what Telhaug and Mediås (2003, p. 443) describe as the transition from the social democratic to the 'corporate economic' school regime. In this regime, the school is seen more as tool for developing the economy and less for developing the individual and to reach social goals.

At the same time, this trend converged with an overall trend where citizens' judicial rights and customer power were promoted as important values in their own right. Citizens were no longer only clients or users of public services but also customers who could and should have demands in regard to the services (Stray, 2009, p. 144). These are contradictory goals since giving customer power to users may result in these users undermining the social investment agenda of the central government.

The attempts to combine the customer power of the citizens with an instrumental use of the school system for economic development can be seen in relation to some important changes to the regulation of the school system. One element was the 
increased use of school choice. This right was strengthened in all three countries throughout the period (Segaard \& Saglie, 2017). In Denmark and Norway, this involves making it easier to change between public schools, while nonprofit schools, especially in Denmark, have remained an alternative to public school, just as they have always been. For-profit schools are outlawed in both these countries, something that has not changed over the last decades. Schools are the responsibility of municipalities, but non-public schools are approved by a state agency in all three countries; the municipality is thus unable to stop them from being established. To avoid non-public schools draining resources from public schools, nonprofit schools are only funded at 71 percent (Denmark) and 85 percent (Norway) of the costs of the student. The parents must pay the rest.

The modest changes in regulation have led to modest changes in the welfare mix in Denmark and Norway. In Denmark, we see a small nonprofit growth at the expense of the public sector, but mostly it is a picture of stability. The public school system has fallen from a share of 86,4 per cent in 2007 to 82,2 per cent in 2016, with a corresponding growth for the nonprofits. Moreover, as documented by Thøgersen (2013), if we go back to the early 1990s, there are still changes of only a few percentage points (Thøgersen, 2013). Norway has a far smaller nonprofit school sector than Denmark. The non-public share of students has grown from 1,9 per cent in 2002 to 3,3 per cent in 2016 (Statistics Norway, 2017a). In 1995 the share was at 1,5 per cent (Berge \& Hyggen, 2011), a level that has been unmoved in decades. All in all, the overall public-non-public mix in Norway is thus stable.

Sweden, however, went further than the other countries (Wiborg, 2013). Since the early 1990s, Sweden has had no limitation based on ownership-nonprofit, and forprofits have been subject to the same regulation. Private schools are fully funded, they are not allowed to charge their students and there is no limitation on the profit they can make. Such a system with full public funding of private alternatives competing for funding with public schools and with no limitation on profits is, to the best of my knowledge, unique for Sweden, and is thus a prime example of market steering. Indeed, in a special issue on the Scandinavian model, The Economist (2013) stated that the neoliberal economist Milton Freeman would feel more at home in Stockholm than in Washington DC (Sivesind \& Trætteberg, 2017)!

The regulatory changes in Sweden have led to considerable changes in the welfare mix. As we can see from Figure 13.1, non-public schools have grown from 1 percent at the start in 1992, to 14,8 per cent today (Skolverket, 2017). The numbers for upper secondary schools are not comparable to the presented numbers for Norway and Denmark, but they are astonishing - going from 1,9 per cent in 1992 to 25,9 per cent today. When this market was first opened up in the early 1990s, the non-public sector consisted primarily of small nonprofit entities and parent cooperatives that offered special pedagogy schools and also some religious schools. This has changed dramatically, however, and today the non-public schools are predominantly for-profit and have the same general profile as public schools. We do not have exact numbers 
on the distribution of for-profit and nonprofit schools, but 'today, the typical owner of an independent school is a joint-stock company’ (Böhlmark \& Lindahl, 2015, p. 512).

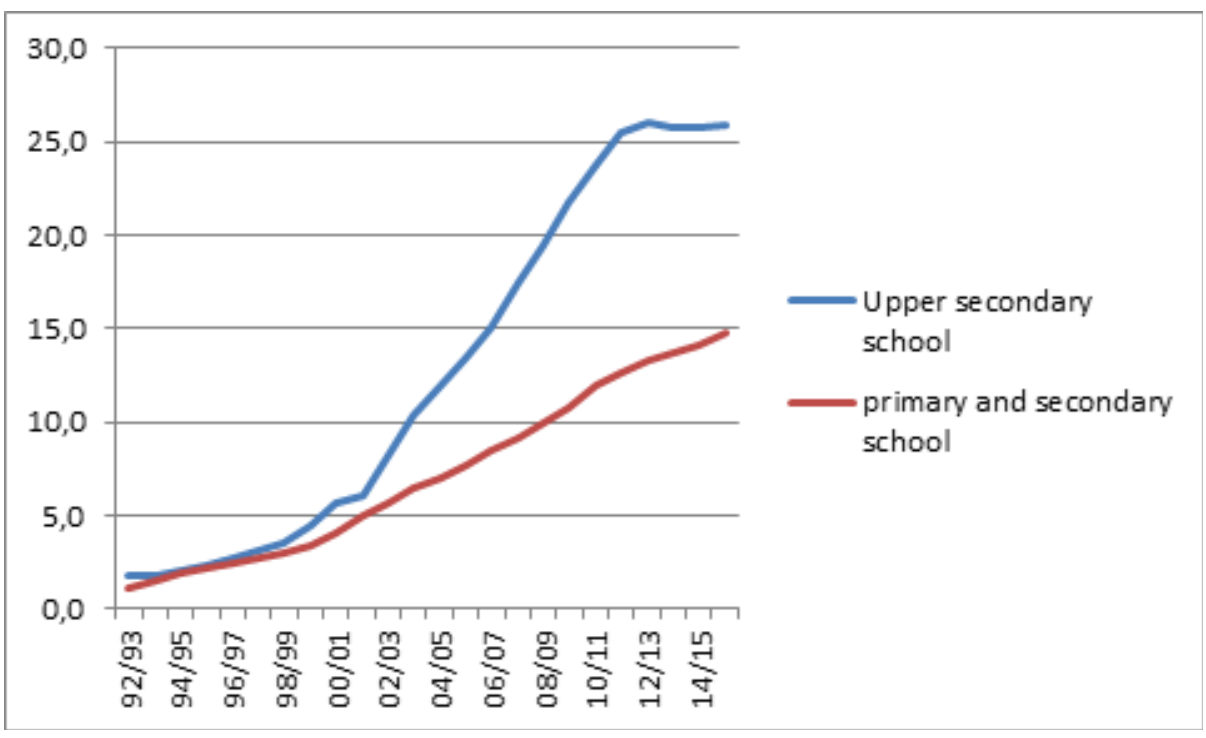

Figure 13.1. Shares of students in non-public schools in Sweden Source: retrieved from (Ekonomifakta, 2016).

\subsection{Elderly Care}

Traditionally, the key concept in Nordic elderly care is 'defamiliarization', which entails that as people get older they should not be forced to depend on their families and other private relations and the state must step up and take responsibility (Daatland, 2012b). This traditional goal is still valid as a description of Scandinavian elderly care; two aspects must, however, be included to complete the picture. By letting the state replace the private bonds of the care receivers, the states have created a dependency of its subjects that has been criticized for being paternalistic. As the population grows more educated, diverse and able and willing to influence the service, user empowerment has thus gained importance (Andersson, 2016; Fredriksson, Blomqvist, \& Winblad, 2012). This is a recurring theme in policy documents in the Nordic countries (e.g. St. Meld. 10 [2012-2013], p. 50; St. Meld. 29 [2012-2013], p. 12).

The second aspect is the demographic changes that challenge all Scandinavian countries. The Nordic countries are comparatively in a better position than many other Western regions, but the number of elderly as a share of the population is growing, and there is a need to prepare elderly care services for the future. A sustainable 
model for sufficient care at an acceptable cost is thus a goal with growing influence (Daatland, 2012a).

Market mechanisms have increasingly been used to achieve both goals. The mechanisms take the form of public tenders, especially for nursing homes, and user choice models, used in home care. These mechanisms are supposed to offer a more efficient provision and to empower the users.

Marketization has in all three countries gone the furthest in home care, where no country had an important nonprofit sector, and the public share in 1990 thus was over 95 per cent. Denmark made it mandatory in 2003 for local authorities to offer choice of provider in home care services (Bertelsen \& Rostgaard, 2013) - which led to a growth in for-profit provision from 2,2 percent of the users in 2004 (Strukturkommissionen, 2004, p. 180) to more than 35 percent today (Statbank Denmark, 2017).

In Norway there has been no major change in the regulation of home care. Thus, only 3 percent of the users of home care services use non-public providers, and these are mainly for-profit actors. The low number is explained by the fact that only 22 out of more than 400 municipalities currently have user choice between private and public providers (NHO, 2016). Many of these 22 municipalities are the largest ones, such as Oslo and Bergen, so a considerable share of the national population is affected by the user choice arrangements in these municipalities.

Sweden has not obliged its municipalities to facilitate for non-public actors, but through 'LOV', or its 'law about free choice', which was enacted in 2009, the municipalities have a blueprint for how to organize a user-choice system with private providers. This has resulted in an expansion of municipalities with for-profit providers competing for users from 6 per cent in 2007 to more half the municipalities in 2013, and the share is continually rising. The result is that whereas 4 per cent used non-public providers in 1990, 25 per cent used non-public providers in 2014, and all the growth occurred in the for-profit sector (Erlandsson et al., 2013; National Board of Health and Welfare, 2015).

In regard to nursing homes, both Denmark and Norway have a tradition of a nonprofit supplement to public provision. When in 2007 Denmark changed the law and gave access to for-profit providers, they did it without disrupting the traditional long-term frame agreement between municipalities and nonprofit providers (Thøgersen, 2015). The result has been a stable development in the welfare mix. Non-public providers operate as the result of public tenders or as 'friplejehjem'. Friplejehjem are independent nursing homes, publicly funded and approved by the national government - the municipality cannot restrict the establishment of a friplejehjem in their municipality. In municipalities that have friplejehjem, citizens can choose these in place of the municipal options. The 'friplejehjem' can be either nonprofit or for-profit; although we do not have good numbers on the distribution, most friplejehjem are most likely nonprofit (Thøgersen, 2015). In total, the number of beds in friplejehjem has grown from 242 in 2009 to about 2.400 in 2016, a small number given that there are approximately 40000 beds in Danish nursing homes 
(Hjelmar et al., 2016). Denmark has tendered out only 15 nursing homes and this form of governance tool has thus not made important changes to the welfare mix (Hjelmar et al., 2016, p. 8).

Norway also has a tradition of long-term frame agreements between municipalities and nonprofit nursing homes. In addition, public tenders have been introduced to include for-profit providers. At the same time, Norway has been the only country in Europe to offer the possibility of having tenders only for nonprofit providers in their procurement legislation. This legislation recently changed as a consequence of the new EU directive on public procurement, which severely reduces the opportunity to reserve tenders for nonprofit providers. However, through a massive advocacy campaign the nonprofit sector demonstrated its influence on policy-making when Parliament decided to maximally exploit the flexibility of the directive to adjust the regulation to be in accordance with the interests of nonprofits. In terms of numbers, nonprofits in 2015 made up 5 percent of the nursing home beds. For-profit nursing homes have grown over recent years and peaked at 6 percent in 2015 (Statistics Norway, 2017b). Over the last decade the changes have only been a couple of percentage points. The local elections in 2015 gave a centre-left leadership in some of the biggest municipalities in Norway something that has led to for-profit nursing homes losing contracts. The public share remains around 90 per cent, as it has been for years.

Sweden has a combination of user choice and public tenders in the nursing home sector, and since it had no important nonprofit sector, there have been no modifications in the regime to safeguard the interests of nonprofits. The result is a growth in non-public provision from 5 per cent in 1990 to 21 per cent in 2014. All this growth is in the for-profit sector (Erlandsson et al., 2013; National Board of Health and Welfare, 2015).

\subsection{What Is Happening?}

When looking at recent developments in the Scandinavian countries over recent decades, some shared observations are pertinent. First, the direction of institutional change is the same, even if the strength in institutional changes varies. In all countries we see some for-profit growth at the expense of the public sector.

Second, when it comes to the regulation of the welfare mix we see variation as Norway and Denmark have had changes in the direction of more market-inspired steering tools, yet mostly with cautious designs that do not produce major changes in the welfare mix. In Sweden, the regulatory changes were radical and led to massive growth in the for-profit sector at the expense of the public sector.

Schools and elderly care are fairly representative for the entire welfare field in the Scandinavian countries. Currently the public sector is about the same size in the welfare fields in all three countries, but the rate of change is different. The nonprofits are keeping their historical share, but the for-profits are gaining ground at the speed 
of, in average change over five years, 4 percentage points in Sweden, less than 2 in Norway and slightly more than 1 in Denmark (Sivesind, 2017).

Whereas the modest changes in Norway and Denmark are in line with what one can observe in many Western regions, the changes in Sweden have the potential to be regime changing. The task is thus to explain the developments in Sweden in a comparative, Scandinavian light.

\subsection{Why the Change in Sweden?}

\subsubsection{Critical Juncture?}

In accordance with theories of path dependency, it is natural to try to understand the changes in Sweden by identifying a critical juncture - a shock that can explain why Sweden in the 1990s replaced governance mechanisms that had made the country the welfare state where the public sector probably provided more services than any other Western country at any time in history (Lundström \& Wijkström, 1997) to become a country that sees unparalleled growth in for-profit providers. There are at least three possible explanations.

\section{Change of political direction}

From 1932 to 1990, the social democrats were in power 53 out of 59 years in Sweden. Could dominance by a different party be an explanation? Right-leaning parties are generally more positive towards market mechanisms. Indeed, it was a centre-right government that took important steps in implementing market reforms in Sweden in the early 1990s (1991-1994) and accelerated the developments with the user choice act in 2009 under the Reinfeldt government (2006-2014). Yet, the social democrats that have ruled in between have not reversed nor dented the development; they have simply been less eager in pushing the developments in the same direction. This attitude of the social democrats suggests the acceptance of market reforms extended far into the social democratic party (Premfors, 1998; Starke, Kaasch, \& Hooren, 2013, p. 116).

The picture is more complicated by the fact that in Denmark, bar four years (2011-2015), a centre-right coalition has ruled since 2001, but with no massive increase in the use of for-profit providers. Likewise, in Norway this has been one of the more hotly debated subjects in various election campaigns, but the current rightwing government has not opened up the school market to for-profit schools and has not made changes in legislation that increases the role of for-profit in elderly care. Moreover, all the municipalities with a conservative majority are free to marketize their elderly care, but few have done it. 


\section{Change in popular support?}

Even if the Scandinavian political parties belong to the same party families across the border, they may be different in ways that can render an analysis of the parties alone incomplete. If we look at popular support, it is noteworthy that when Swedes are asked who should provide the services, the share that chooses the alternative 'state and local authorities' remained remarkably stable from 1980 to 2010 (Svallfors, 2016, p. 27). In other words, at the same time the welfare mix changed massively there was no movement in popular opinion on the issue, suggesting that popular demand cannot explain the changes. In Denmark, there had been a growing public resistance to privatization from 1989 to 2007, with a small reversal in 2011 (Stubager, Holm, Smidstrup, \& Kram, 2013, p. 49). This is curious as the for-profit sector has grown in Denmark during this period, but it is unclear if popular resistance to privatization has dented the development. In Norway, Aardal (2015, p. 66) finds that over the period from 2005 to 2009 there was an increase in support for private solutions, even as a centre-left government won the 2009 election, but that there was no growth in support for private solutions in the years leading up to the 2013 election where parties at the right entered government. Consequently, changes in popular support for private providers do not seem to be the driving force between the developments in any of the three countries, even if it possibly did play a part for example in Denmark.

\section{Economic shock}

The described institutional changes in Swedish welfare coincided with an economic downturn in the early 1990s. This makes it tempting to conclude that the economic crisis opened a window of opportunity for more radical change. Interestingly, Norway experienced a major banking crisis in about the same period as Sweden, and Denmark also experienced a severe economic downturn a few years before Sweden. Yet, in these countries we do not see the same consequences when it comes to marketization (Wiborg, 2009, p. 409).

The Swedish crisis was, however, deeper than in the other countries, and the economic shock indeed led to changes in the Swedish welfare state, most notably in transfers generally and in the pension system particularly (Bergmark \& Palme, 2003). The changes must not be overstated, and, when comparing with other Western countries, Lindbom (2001) has found that 'generosity, universality and developed welfare services - are almost as prominent as before the crisis'. Indeed, Blomqvist (2004) argues that the 'revolution' in Swedish welfare in the 1990s was not in changes in willingness to spend, but rather in the fashion in which services were delivered. When looking at the arguments at the time it is also clear that economic arguments were not the most prominent ones. When entering office in 1991, conservative Prime Minister Carl Bildt promised to create 'the best school in Europe' during the 1990s based on a scheme with 'school choice for everyone' and where money followed the pupils (Bildt, 1991). Indeed, already before the crisis there seems to have been an agreement - extending far into the social democratic party (Green-Pedersen, 2002) 
- that the domination of the state had been too extensive and that market-oriented reforms were necessary.

While the economic crisis may not have been decisive in generating these changes in Swedish welfare services (Green-Pedersen, 2002, p. 284), an academic expert group assessing the consequences of the economic crisis on Swedish welfare found that it 'triggered policy change in virtually all areas' of Swedish welfare policy (Palme et al., 2002, p. 329). The initial changes in the welfare mix thus came about at a time in which the economic crisis had created opportunities for change in the model. It is not possible to argue that the welfare mix was the one aspect of Swedish welfare that was not touched by the crisis. The concurrence of crisis and radical change in the welfare mix is therefore no coincidence, even if a movement in the same direction in any case would have been likely.

\subsection{Incremental Changes?}

In spite of the role of the crisis, the main puzzle remains. In the Swedish debate in the early 1990s local entrepreneurs and cooperatives and other locally entrenched initiatives were foreseen as an important part of the private alternatives, as quality improvements were the main rationale for the regulatory changes (Ruwaida, Pertoft, \& Amin, 2013; Stryjan \& Wijkström, 1996). Later, cost containment became a more central argument (Blomqvist, 2004). Today, the ownership of private welfare is concentrated, and the private companies in the welfare sector are often owned by investment funds based in tax havens (Dahlgren, 2014, p. 512). It seems obvious that what we have today is different from what policy-makers expected 30 years ago.

When looking at the regulation of these services, the Scandinavian countries have ended up with different mechanisms for how to obtain the goals they share. Can an explanation be found in the mechanisms that can produce big changes over time through small, incremental steps?

In Denmark, the nonprofit welfare sector has an unbroken, centuries-long tradition, which was never diminished to near irrelevance as it was in Sweden (Henriksen \& Bundesen, 2004). Moreover, nonprofit institutions in Denmark already contributed to the diversity in services, making the political need to expand the nonpublic sectors less acute since people already had a broader set of services to choose from. Denmark has a long tradition of promoting diversity in services and user choice, while Norway and Sweden have had more emphasis on the legal rights of users (Andersen \& Hoff, 2001).

The Danish nonprofit institutions have their roots in different parts of society. Particularly the schools represent the whole range of society; there are for example schools with bases in conservative, liberal and socialist movements. This enables the nonprofits to find allies in all political movements and parties. Mechanisms that 
would unduly promote for-profit actors at the expense of nonprofits were therefore not acceptable.

Norway was in many ways a lighter version of the same story. Although having a nonprofit sector only half the size of Denmark's, it was present in many welfare areas, organized and willing to fight for its position. There are different examples of how the nonprofit sector has obtained beneficial public regulation; an important case is the reserved tenders for nonprofits where for-profit actors cannot compete. To ensure the state is aware of the interests of nonprofits, there are exclusive meeting points between nonprofit representatives and the state. The nonprofit sector has good alliances with the centrist political parties that often tip the balance of the parliamentarian majority. In addition, nonprofits are regarded as part of the member-based civil society, which, as we have seen numerous examples of, has an unparalleled access to decision-makers in government and parliament. An additional feature in Norway may be that the powerful public sector unions forcefully worked against all attempts at marketization in a way that was not equalled by the unions in Denmark and Sweden (Vabø, Christensen, Jacobsen, \& Trætteberg, 2013).

Denmark and Norway thus have a layered framework for how to engage with nonpublic providers. Some were used before market mechanisms came to the fore, and they still exist: Nonprofit providers still have long-term contracts with municipalities without being exposed to competition with for-profits. School plurality was already in place, so the need to open up for for-profit schools was not acute. What we see are parallel systems for relations with non-public providers, some established before 'the era of marketization' and others being market-based.

In Sweden, the expansion of the welfare state in the post-World War II era entailed the public sector crowding out the nonprofits that had historically been present (Lundbäck \& Lundberg, 2012). When Sweden started breaking up the public dominance in the 1990s it thus had a very weak nonprofit sector, which did not represent an alternative to the public sector. In face of demands for more plurality in services, policy-makers could not rely on the nonprofit sector.

The weak position of the nonprofit sector also meant that when non-public growth was expected, this sector was unable to step up and expand their share of the services - any expansion in terms of alternative providers thus came from the for-profit sector. Lacking the ability to attract financing in order to upscale operations is a well-known liability of nonprofits, something that has also been shown to be the case in Sweden (Jutterström et al., 2016). Sweden's weak institutional capacity for engaging non-public providers in public services forced it to base the relations to non-public providers entirely on new mechanisms, and Sweden ended up with a less multifaceted - or layered - toolkit for public-private cooperation. It is therefore wrong to regard the framework for public-non-public relations in Sweden as layered; it is practically all market-driven relations, something that creates an entirely different dynamic than that in the other Scandinavian countries. When the governance tools are 'blind' to the for-profit-nonprofit divide, the for-profits gain an edge because of 
their ability to finance rapid upscaling and financial muscle to endure in the market in spite of losing one contract.

The changes in Sweden have been drastic, and they are in line with the interest of groups that saw their influence in society grow at the same time as the changes to the Swedish welfare mix gained traction. The Swedish conservative government that assumed power in 1991 lined up with private businesses with a more radical ideological shift than what had been the case in the other Scandinavian countries (Sejersted, 2005, p. 397). There was accordingly more willingness in Sweden to challenge existing rules and enact them in new ways than what was the case in Denmark and Norway. This invites questioning whether what has taken place is a conversion, that a coalition of stakeholders have altered the rules but without formally changing them. The fact that it took some time from the opening up of the public monopoly before the for-profit growth took off can be interpreted as a period where for-profit entrepreneurs and right-wing politicians redeployed the basic understanding of the rules. Seen in this way, the reinterpretation is more a matter of a political conquest of the understanding of the rules than the material changes to them.

The problem with viewing this as a result of conversion is that while new rules have indeed been introduced that have produced the for-profit growth, 80 percent of Swedish welfare is still public, and the traditional dominance of the public sector is thus intact. What has happened is that regulation such as public tender laws and the law about free choice (LOV) have come as additions, layered on the existing regime. This exemplifies that even when the existing rules within an institution are not reinterpreted or changed, radical change can occur when the new layers are sufficiently consequential.

To sum up, Norway and Denmark have changed in the direction of more marketinspired steering tools, yet mostly with cautious designs to guard the traditional values and organizing principles of the services. The result has been modest for-profit growth at the expense of the public sector, with a stable share for the nonprofit sector. The exception is in Danish home care, where there has never been an important nonprofit alternative and where for-profits have gained a large share of the market. In Sweden, the regulatory changes were radical and led to a massive growth in the for-profit sector at the expense of the public sector. The nonprofit sector has always been small and has not been able to grow under the new circumstances. Table 13.1 summarizes the relationship between nonprofit tradition and for-profit growth.

This shows the importance of the role of the nonprofit sector at the time when the three countries started increasing their use of market mechanisms. 
Table 13.1. For-profit growth and nonprofit tradition in the Scandinavian countries

\begin{tabular}{|c|c|c|c|}
\hline & & \multicolumn{2}{|c|}{ Important for-profit growth? } \\
\hline & & yes & No \\
\hline \multirow[t]{8}{*}{ Nonprofit tradition } & yes & None & Norway - schools \\
\hline & & & Norway - nursing homes \\
\hline & & & Denmark - schools \\
\hline & & & Denmark - nursing homes \\
\hline & no & Sweden - home care & Norway - home care \\
\hline & & Sweden - nursing homes & \\
\hline & & Sweden - schools & \\
\hline & & Denmark - home care & \\
\hline
\end{tabular}

\subsection{Sweden, Democracy and the Future of the Nordic Welfare System}

The changes that have taken place in Sweden are not inherently democratic or undemocratic. Rather, the democratic value can be examined through looking at two issues: first, the consequences the changes have for the services the citizens receive - the outcomes of democratic processes; second, whether the changes have created a path-dependent development that is difficult to alter within the ordinary democratic process.

On the first issue, the Nordic societies have become more diverse, and thus to retain their democratic legitimacy, universal welfare arrangements need to cater to a diverse set of citizens. A key question is thus whether more plurality in providers gives more plurality in the content of service.

In regard to elderly care, evidence suggests there are small differences between public and non-public providers. In an interview study Stolt, Blomqvist and Winblad (2011) found that for-profit nursing homes in Sweden have better scores when it comes to service-related quality, such as having various meals to choose from, while public nursing homes have more employees per user and a better-educated workforce. In a study inspired by this approach, Hjelmar et al. (2016) found very small differences between public and non-public nursing homes in Denmark. In Norway there are no such quantitative measures, but a qualitative study by Trætteberg (2015) suggests the differences are also limited in Norway. These are measures of quality, but also when it comes to distinctiveness in terms of substance, the evidence suggests that a broadening of types of providers does not give a broadening in the content offered to the citizens (Feltenius, 2017).

In the school sector, the picture is somewhat different. As we have seen, Sweden has a strong emphasis on school choice, but is the only country in Scandinavia that does not have different laws governing private and public schools (Segaard \& Saglie, 
2017). This might be part of the explanation why there are small differences between public and private schools in Sweden (Thøgersen, 2017). In contrast, Denmark and Norway have different laws regulating public and non-public schools. Indeed, nonpublic schools in Norway are obliged to offer an alternative to public school in terms of teaching philosophy or religion. In Denmark the values of the nonprofit school must be readily available on the webpage of the school. The Danish nonprofit schools offer a variety of philosophical and religious content and have deep-seated traditions in Danish society. The nonprofit schools in Denmark and Norway thus represent a real expansion of service content to the citizens (Thøgersen, 2017).

As an expansion of the democratic autonomy of citizens, the Swedish for-profit expansions seem to render little meaningful expansion of alternatives to choose from. Yet, the mere possibility to choose may be valuable as a democratic tool, and there are studies suggesting that user choice as an independent value in the welfare system has grown in Sweden as citizens and policy-makers have grown accustomed to it (Burström, 2015). To be able to exit a provider one is dissatisfied with may change power relations between the user and the service provider (Hirschman, 1970). Yet, given the social costs of the change of human services, the exit possibility seems less relevant than having substantive alternatives to choose from. Interestingly, the Danish (and Norwegian) example with a strong nonprofit sector seems to produce broader service content.

Looking at the second issue of path dependency and possibilities to alter the development, it is interesting that the current centre-left government in Sweden has made the limitation (or abolition) 'of making a profit in the welfare system' a central policy issue. Technically, these services are publicly funded and tightly regulated; to take back the provision is thus not a theoretical problem. The creation of a 'welfare market' has, however, changed some dynamics that provoke questions about how realistic it is for Swedish policy-makers to change course, if that is what they want. In other words, how can institutional change be achieved from the current situation in Swedish welfare services?

An expert committee commissioned by the government recently gave advice on how to limit 'profit in welfare' (SOU 2016:78). There was great expectation in regard to this work, but the resulting report seems more like evidence of the lack of alternatives for policy-makers rather than useful tools for how to change the dynamic of the market. It thus looks like the present government will follow earlier social democrats in limiting themselves to 'slowing the speed' but going in the same direction of increasing the share of for-profit providers. Why is this development so difficult to change?

First, the for-profit companies have gained considerable market power. When forprofit providers deliver 20 percent of a service, the government that is responsible to the citizens depends on these providers. This gives them power over the regulation of the field, and these companies are willing to use this power. Remember, these 
companies are often owned by foreign investment funds and are hence unwilling to compromise on their expected return on investment.

Second, and related, is the capacity to advocate. The advocacy groups promoting the different sectors grow stronger as their share grows. In Sweden, the groups promoting the interests of for-profit providers are stronger than those found in Norway and Denmark. At the same time, the ones defending the interests of nonprofits are weaker.

Third, consumer choice may have created dynamics that would be difficult to contain even if one wanted. Users get used to choice and exit alternatives according to their preferences. It is easier to not introduce such schemes in the first place than it is to roll them back. Proponents can therefore push such arrangements in ever-new fields without experiencing many setbacks.

The fourth reason entails ideas of what the 'normal' way is to organize welfare. In Norway, and to some degree in Denmark, stakeholders wanting to curb the growth of for-profits argue from a point of strength, showing how for-profits in many areas are alien to the welfare model. The population expects schools and some other services to be nonprofit, as they have always been. These forces have lost the battle in Sweden, as they have also done in some fields in Denmark (home care) and Norway (child care). In these sectors the normal way is to use the same tools for engaging nonprofit and forprofit providers, resulting in for-profit growth at the expense of other sectors. Edlund and Sevä (2013) demonstrate this effect when they show how citizens in Swedish municipalities with little privatization are more supportive of public provision than citizens in municipalities where private alternatives are more widespread.

Given these mechanisms, it is difficult to see the Swedish welfare state making changes in the welfare mix towards growing shares for the public or nonprofit sectors. Indeed, there are currently no signs that the for-profit sector growth will cease to continue. Rather, it looks like the aforementioned mechanisms make the current development the subject of path dependency. As it stands now, large-scale events may be necessary to produce profound changes moving away from for-profit growth.

The central argument in this chapter is that the rapid increase in for-profit provision in Sweden is best explained by the aggregated process of layering, where public regulation has one fewer layer compared to Denmark and Norway due to lacking a nonprofit tradition. At the same time, it is evident that the economic crisis also played a role in facilitating developments in this particular direction. If an external shock is necessary for a reduction in for-profit growth, it is yet another example that combining different theoretical approaches is necessary to obtain a good understanding of developments in the welfare mix in Scandinavia.

Even if the changes happening in Sweden look transformative today, we must remember that Sweden in the 1980s had the highest level of public provision ever seen in a Western country. Today the public sector's share of the provision of welfare is at the same level as that in Denmark and Norway (Sivesind, 2017). The last ten years have proved that the bourgeois parties have accepted state funding and the regulation of 
services while at the same time the social democrats have accepted private provision. As Svallfors (2016, p. 31) writes: 'The electoral base for resistance against high-tax, high-spending, collective welfare state now looks more or less eroded'. Currently, the Swedish population is content with their welfare system, and more so than they were in 1990 (Lindbom, 2016, p. 48).

The Scandinavian countries have always differed from each other in spite of all their similarities. Denmark has always had more choice and more non-public providers because of its strong tradition of nonprofit providers. However, the speed and profoundness of the changes in Sweden provoke questions as to whether the welfare system is going through a transition through marketization. At the pace these changes are happening it is an open question whether Sweden can remain within the same model for long, and it is also an open question as to whether one can talk of a Nordic system with no Swedish member.

\section{References}

Aardal, B. (2015). Offentlig opinion - folkets vilje eller tilfeldige ytringer? In B. Aardal \& J. Berg (Eds.), Valg og velgere. En studie av stortingsvalget 2013 (49-75). Oslo: Cappelen Damm Akademisk.

Andersen, J. G., \& Hoff, J. V. (2001). Democracy and Citizenship in Scandinavia. New York: Palgrave Macmillan.

Andersen, J. G., \& Rossteutscher, S. (2007). Small-Scale Democracy: Citizen Power in the Domains of Everyday Life. In J. W. Van Deth, J. R. Montero \& A. Westholm (Eds.), Citizenship and Involvement in European Democracies: A Comparative Analysis. Oxon: Routledge.

Andersson, K. (2016). Individualisering. In S. Johansson \& A. T. Larsson (Eds.), Förändringsperspektiv pä äldreomsorg. Malmø: Gleerups.

Berge, Ø., \& Hyggen, C. (2011). Privatskoler i Norden. Omfang, utvikling og den politiske debatten. Oslo: Fafo.

Bergmark, A., \& Palme, J. (2003). Welfare and the unemployment crisis: Sweden in the 1990s. International Journal of Social Welfare, 12(2), 108-122.

Bertelsen, T. M., \& Rostgaard, T. (2013). Marketisation in Eldercare in Denmark: Free Choice and the Quest for Quality and Efficiency. In G. Meagher \& M. Szebehely (Eds.), Marketisation in Nordic Eldercare: a Research Report on Legislation, Oversight, Extent and Consequences (127-162). Stockholm: Stockholm University; Department of Social Work.

Bildt, C. (1991). Riksdagens snabbprotokoll 1991/92:6 Fredagen den 4 oktober. Stockholm: Riksdagen. Retrieved from https://www.riksdagen.se/sv/dokument-lagar/dokument/protokoll/ riksdagens-snabbprotokoll-1991926-fredagen-den_GF096.

Blomqvist, P. (2004). The Choice Revolution: Privatization of Swedish Welfare Services in the 1990s. Social Policy \& Administration, 38(2), 139-155.

Blomqvist, P., \& Rothstein, B. (2008). Välfärdsstatens nya ansikte: demokrati och marknadsreformer inom den offentliga sektorn. Stockholm: Agora.

Burström, B. (2015). Sweden - Recent Changes in Welfare State Arrangements. International Journal of Health Services, 45(1), 87-104.

Böhlmark, A., \& Lindahl, M. (2015). Independent Schools and Long-run Educational Outcomes: Evidence from Sweden's Large-scale Voucher Reform. Economica, 82(327), 508-551. 
Chaves, M. (1998). The Religious Ethic and The Spirit of Nonprofit Entrepreneurship. In E. S. Clemens \& W. W. Powell (Eds.), Private Action and the Public Good. New Haven, Conn.: Yale University Press.

Daatland, S. O. (1997). De siste årene. Eldreomsorgen i Skandinavia 1960-95. Oslo: NOVA.

Daatland, S. O. (2012a). Aldringen av befolkningen og eldreomsorgen - hensikten og problemstillingene. In S. O. Daatland \& M. Veenstra (Eds.), Bærekraftig omsorg? Familien, velferdsstaten og aldringen av befolkningen. Oslo: NOVA.

Daatland, S. O. (2012b). Komparative perspektiver på omsorgstjenestene - Norge i en internasjonal sammenheng. In S. O. Daatland \& M. Veenstra (Eds.), Bærekraftig omsorg? Familien, velferdsstaten og aldringen av befolkningen. Oslo: NOVA.

Dahlgren, G. (2014). Why Public Health Services? Experiences from Profit-Driven Health Care Reforms in Sweden. International Journal of Health Services, 44(3), 507-524.

Edlund, J., \& Sevä, I. J. (2013). Is Sweden Being Torn Apart? Privatization and Old and New Patterns of Welfare State Support. Social Policy \& Administration, 47(5), 542-564.

Ekonomifakta. (2016). Elever i friskola. Retrieved from http://www.ekonomifakta.se/Fakta/ Valfarden-i-privat-regi/Skolan-i-privat-regi/Elever-i-friskola/ [Accessed March 13, 2017].

Engelstad, F., \& Hagelund, A. (2015). Introduction: Institutional Change in Neo-Corporatist Society. In F. Engelstad \& A. Hagelund (Eds.), Cooperation and Conflict the Nordic Way. Work, Welfare, and Institutional Change in Scandinavia (1-16). Berlin: De Gruyter.

Erlandsson, S., Storm, P., Stranz, A., et al. (2013). Marketising trends in Swedish eldercare: competition, choice and calls for stricter regulation. In G. Meagher \& M. Szebehely (Eds.), Marketisation in Nordic Eldercare: a Research Report on Legislation, Oversight, Extent and Consequences. Stockholm: Department of Social Work, Stockholm University.

Feltenius, D. (2017). Elderly care in Scandinavia: Marketization and local governing of nursing homes. In K. H. Sivesind \& J. Saglie (Eds.), Promoting Active Citizenship? Markets and Choice in Scandinavian Welfare. London: Palgrave MacMillan.

Fredriksson, M., Blomqvist, P., \& Winblad, U. (2012). The Trade-off Between Choice and Equity: Swedish Policymakers' Arguments when Introducing Patient Choice. Journal of European Social Policy, 23(2), 192-209.

Green-Pedersen, C. (2002). New Public Management Reforms of the Danish and Swedish Welfare States: The Role of Different Social Democratic Responses. Governance, 15(2), 271-294.

Gustavsen, A., Røiseland, A., \& Pierre, J. (2014). Procedure or Performance? Assessing Citizen's Attitudes Toward Legitimacy in Swedish and Norwegian Local Government. Urban Research \& Practice, 7(2), 200-212.

Henriksen, L. S., \& Bundesen, P. (2004). The Moving Frontier in Denmark: Voluntary-state Relationships since 1850. Journal of social policy, 33(04), 605-625.

Hirschman, A. O. (1970). Exit, Voice, and Loyalty: Responses to Decline in Firms, Organizations, and States (Vol. 25): Cambridge, Mass.: Harvard University Press.

Hjelmar, U., Bhatti, Y., Rostgaard, T., et al. (2016). Kvalitet på offentlige og private plejecentre i Danmark. Roskilde: Roskilde Universitet.

Hogan, J. (2006). Remoulding the Critical Junctures Approach. Canadian Journal of Political Science, 39(03), 657-679.

Jutterström, M., Kernen, J., Segnestam Larsson, O., \& Hedlin, D. (2016). Ideella organisationer i välfärden: Finansiella förutsättningar vid etablering, expansion och löpande verksamhet. Stockholm: Stockholms universitet.

Kumlin, S. (2004). The Personal and the Political: How Personal Welfare State Experiences Affect Political Trust and Ideology. New York: Palgrave Macmillan.

Le Grand, J. (2007). The Other Invisible Hand: Delivering Public Services through Choice and Competition. Princeton: Princeton University Press. 
Lehto, J., Moss, N., \& Rostgaard, T. (1999). Universal Public Care and Health Care Services In M. Kautto, M. Heikkilä, B. Hvinden, S. Marklund \& N. Ploug (Eds.), Nordic social policy. changing welfare states. London: Routledge.

Lindbom, A. (2001). Dismantling the Social Democratic Welfare Model? Has the Swedish Welfare State Lost Its Defining Characteristics? Scandinavian Political Studies, 24(3), 171-193.

Lindbom, A. (2016). Political Partisanship and Policy Feedback: The Swedish Welfare State after Eight Years of Center-Right Government. In J. Pierre (Ed.), The Oxford Handbook of Swedish Politics. Oxford: Oxford University Press.

Lundbäck, M., \& Lundberg, A. (2012). Varför är det så få idéburna organisationer i välfärden? Stockholm: Tillväxtverket.

Lundström, T., \& Wijkström, F. (1997). The Nonprofit Sector in Sweden. Manchester: Manchester University Press.

Mahoney, J., \& Thelen, K. (2010). A Theory of Gradual Institutional Change. In J. Mahoney \& K. Thelen (Eds.), Explaining Institutional Change. Ambiguity, Agency, and Power. Cambridge: Cambridge University Press.

National Board of Health and Welfare (2015). Äldre och personer med funktionsnedsättning regiform år 2014. Stockholm: Socialstyrelsen.

NHO (2016). Statistikk og Trender 2016-17. Oslo: NHO Service.

Palme, J., Bergmark, A., Backman, O., et al. (2002). Welfare Trends in Sweden: Balancing the Books for the 1990s. Journal of European Social Policy, 12(4), 329-346.

Petersson, O., Westholm, A., \& Blomberg, G. (1989). Medborgarnas makt. Stockholm: Carlssons.

Pierson, P. (2000). Increasing Returns, Path Dependence, and the Study of Politics. American Political Science Review, 94(02), 251-267.

Pierson, P. (2004). Politics in Time. History, Institutions and Social Analysis. Princeton, N): Princeton University Press.

Pollitt, C., \& Bouckaert, G. (2011). Public Management Reform: A Comparative Analysis - New Public Management, Governance, and the Neo-Weberian State. Oxford: Oxford University Press.

Premfors, R. (1998). Reshaping the Democratic State: Swedish Experiences in a Comparative Perspective. Public Administration, 76(1), 141-159.

Rostgaard, T. (2015). Når fortiden er længere end fremtiden. Stockholm: Nordens Välfärdscenter.

Rothstein, B. (1993). The Crisis of the Swedish Social Democrats and the Future of the Universal Welfare State. Governance, 6(4), 492-517.

Rothstein, B. (1998). Just Institutions Matter: The Moral and Political Logic of the Universal Welfare State. Cambridge: Cambridge University Press.

Rothstein, B. (2009). Creating Political Legitimacy: Electoral Democracy Versus Quality of Government. American Behavioral Scientist, 53(3), 311-330.

Ruwaida, Y., Pertoft, M., \& Amin, J. (2013). Förlåt, vår politik har lett skolan fel, Aftonbladet. Retrieved from http://www.aftonbladet.se/debatt/debattamnen/skola/article17777394.ab.

Salamon, L. M. (1987). Of Market Failure, Voluntary Failure, and Third-party Government: Toward a Theory of Government-nonprofit Relations in the Modern Welfare State. Nonprofit and voluntary sector quarterly, 16(1-2), 29-49.

Seeleib-Kaiser, M. (Ed.). (2008). Welfare State Transformations: Comparative Perspectives. London: Palgrave Macmillan UK.

Segaard, S. B., \& Saglie, J. (2017). Education and Elderly Care in Denmark, Norway and Sweden: National Policies and Legal Frameworks for Private Providers. In K. H. Sivesind \& J. Saglie (Eds.), Promoting active citizenship? Markets and Choice in Scandinavian Welfare. London: Palgrave MacMillan.

Sejersted, F. (2005). Sosialdemokratiets tidsalder. Norge og Sverige i det 20. århundre. Oslo: Pax forlag. 
Sejersted, F. (2011). The age of Social Democracy. Norway and Sweden in the Twentieth Century. Princeton: Princeton University Press.

Sipilä, J. (1997). Social Care Services: The key to the Scandinavian Welfare Model. Michigan: Avebury Aldershot.

Sivesind, K. H. (2017). The Changing Role of Private for-Profit and Nonprofit Welfare Provision in Norway, Sweden and Denmark, and Consequences for the Scandinavian Model. In K. H. Sivesind \& J. Saglie (Eds.), Promoting Active Citizenship? Markets and Choice in Scandinavian welfare. London: Palgrave MacMillan.

Sivesind, K. H., \& Trætteberg, H. (2017). Does Out-contracting of Welfare Services Promote Active Citizenship? In K. H. Sivesind \& J. Saglie (Eds.), Promoting active citizenship? Markets and choice in Scandinavian welfare. London: Palgrave MacMillan.

Skolverket. (2017). Skolor och elever i grundskolan. Retrieved from https://www.skolverket.se/ statistik-och-utvardering/statistik-i-tabeller/grundskola/skolor-och-elever [Accessed March 13, 2017].

Solevid, M. (2009). Voices from the Welfare State. Dissatisfaction and Political Action in Sweden. Gothenburg: University of Gothenburg.

SOU 2016:78. Ordning och reda i välfärden. Stockholm: Statens Offentliga utredningar.

St. Meld. 10 (2012-2013). God kvalitet - trygge tjenester - Kvalitet og pasientsikkerhet $\mathrm{i}$ helse- og omsorgstjenesten. Oslo: Helse- og omsorgsdepartementet.

St. Meld. 29 (2012-2013). Morgendagens omsorg. Oslo: Helse- og omsorgsdepartementet.

Starke, P., Kaasch, A., \& Hooren, F. v. (2013). The Welfare State as Crisis Manager. Explaining the Diversity of policy Responses to Economic Crisis. London: Palgrave Macmillan.

Statbank Denmark. (2017). AED012: Recipients of home care, free choice, who use private contractor by region, type of benefits, age and sex. Retrieved from https://www.statbank.dk/statbank5a/ default.asp?w=1920 [Accessed March 13, 2017].

Statistics Norway. (2017a). Table: 05232: Pupils in primary and lower secondary school, by class level, tenure status and type of institution (C). Retrieved from https://www.ssb.no/statistikkbanken/SelectVarVal/Define.asp?MainTable=ElevarGrunnSk\&KortNavnWeb=utgrs\&PLangu age $=1 \&$ checked $=$ true $[$ Accessed March 13, 2017].

Statistics Norway. (2017b). Table: 09929: Institutions for the aged and disabled, by ownership (C). Retrieved from https://www.ssb.no/statistikkbanken/selectvarval/Define.asp?subjectcode

$=\&$ Productld $=\&$ MainTable $=$ HelsOmsInst $\&$ nvl $=\&$ PLanguage $=1 \&$ nyTmpVar $=$ true $\& C M S S u b j e c t A r e a=h$ else\&KortNavnWeb=pleie\&StatVariant $=\&$ checked=true [Accessed March 13, 2017].

Steinberg, R. (2006). Economic Theories of Nonprofit Organizations. In W. W. Powell \& R. Steinberg (Eds.), The Nonprofit Sector: A Research Handbook (117-139). New Haven, Conn.: Yale University Press.

Stolt, R., Blomqvist, P., \& Winblad, U. (2011). Privatization of Social Services: Quality Differences in Swedish Elderly Care. Social Science \& Medicine, 72(4), 560-567.

Stray, J. H. (2009). Demokratisk medborgerskap i norsk skole? En kritisk analyse. (PhD. Thesis, University of Oslo, Oslo, Norway).

Streck, W., \& Thelen, K. (2005). Introduction: Institutional Change in Advanced Political Economies. In W. Streck \& K. Thelen (Eds.), Beyond Continuity. Institutional Change in Advanced Political Economies (3-39). Oxford: Oxford University Press.

Strukturkommissionen (2004). Strukturkommissionens betænkning - Bind III. Retrieved from http:// www.oim.dk/media/17099/strukturkommissionens-betaenkning-bilag-sektorkapitler.pdf.

Stryjan, Y., \& Wijkström, F. (1996). Cooperatives and Nonprofit Organizations in Swedish Social Welfare. Annals of public and cooperative economics, 67(1), 5-27.

Stubager, R., Holm, J., Smidstrup, M., \& Kramb, K. (2013). Danske vælgere 1971-2011. En oversigt over udviklingen i vælgernes holdninger mv. Retrieved from http://www.valgprojektet.dk/files/ Danske\%20v\%C3\%A6lgere\%201971-2011\%20-\%20Februar\%202013.pdf. 
Svallfors, S. (2016). Who Loves the Swedish Welfare State? Attitude Trends 1980-2010. In J. Pierre (Ed.), The Oxford Handbook of Swedish Politics. Oxford: Oxford University Press.

Szebehely, M. (2014). How Sustainable are Current Provisions of Elderly Care: Ageing Populations, Gender Relations and Emerging Public/Private Divisions of Responsibility. Keynote Speech, ESPAnet Conference 4-6 september 2014, Oslo and Akershus University College of Applied Sciences, Oslo.

Telhaug, A. O., \& Mediås, O. A. (2003). Grunnskolen som nasjonsbygger. Fra statspietisme til nyliberalisme. Oslo: Abstrakt forlag.

Telhaug, A. O., Mediås, O. A., \& Aasen, P. (2006). The Nordic Model in Education: Education as Part of the Political System in the last 50 years. Scandinavian Journal of Educational Research, 50(3), 245-283.

The Economist. (2013, February 2). The Nordic countries. The next supermodel. Retrieved from https://www.economist.com/news/leaders/21571136-politicians-both-right-and-left-couldlearn-nordic-countries-next-supermodel.

Thuen, H., \& Tveit, K. (2013). Privatskolane - vere eller ikkje vere? Fire hundre år i motgang og medgang. Tidsskrift for samfunnsforskning, 54(04), 493-508.

Thøgersen, M. (2013). Selvejende institutioner i Danmark. Institutionernes udvikling, udbredelse og karakter på udvalgte samfundsområder. Aalborg: Netværk for forskning i Civilsamfund og Frivillighed.

Thøgersen, M. (2015). Offentlige og frivillige velfærdsudbydere og aktivt medborgerskab - En analyse af plejehjems- og skoleområdet i to udvalgte kommuner. Aalborg: Netværk for forskning i Civilsamfund og Frivillighed.

Thøgersen, M. (2017). Primary Schools in Scandinavia: Local Governing and Different Types of Providers. In K. H. Sivesind \& J. Saglie (Eds.), Promoting Active Citizenship? Markets and Choice in Scandinavian Welfare. London: Palgrave MacMillan.

Trætteberg, H. (2015). Public, For-Profit, and Nonprofit Welfare Institutions in Norway: Distinctive Goals and Steering Mechanisms or Hybridity in a Dominant State. VOLUNTAS: International Journal of Voluntary and Nonprofit Organizations, 26(5), 1620-1638.

Trætteberg, H. (2016a). Does Welfare Mix Matter? Active Citizenship in Public, For-profit and Nonprofit Schools and Nursing Homes in Scandinavia. (P.hD. Thesis, University of Oslo, Oslo).

Trætteberg, H. (2016b). User Democracy in Schools? Comparing Norwegian Schools with Nursing Homes. Scandinavian Journal of Educational Research. doi: 10.1080/00313831.2016.1188149

Vabø, M., Christensen, K., Jacobsen, F. F., \& Trætteberg, H. (2013). Marketization in Norwegian Eldercare. Preconditions, Trends and Resistance. In G. Meagher \& M. Szebehely (Eds.), Marketisation in Nordic Eldercare: A Research Report on Legislation, Oversight, Extent and Consequences (163-202). Stockholm: Noma care.

Weisbrod, B. A. (1988). The Nonprofit Economy. Mass.: Harvard University Press.

Wiborg, S. (2009). Education and Social Integration: Comprehensive Schooling in Europe. Secondary Education in a Changing World. New York: Palgrave Macmillan.

Wiborg, S. (2013). Neo-liberalism and Universal State Education: The Cases of Denmark, Norway and Sweden 1980-2011. Comparative Education, 49(4), 407-423.

Young, D. R. (2013). If not for profit, for what? Atlanta: Lexington Books. 